\title{
A NEW SPECIES OF PRUNUS FROM COLOMBIA
}

\section{Richard Evans Schultes and Hernando Garcí a-Barriga}

This beautiful shrubby species of Prunus from the highland area of central Colombia has been introduced to cultivation in the gardens of the Instituto de Ciencias Naturales of the Universidad Nacional in Bogotá. We believe that it is worthy of more generalized use as an ornamental in regions appropriate for its growth.

We take great pleasure in naming this species in honour of $\mathrm{His}$ Excellency, Dr. Belisario Betancur, President of the Republic of Colombia, in recognition of his long interest in the furtherance of investigations in the natural sciences in his country.

\section{Prunus Betancurii $R$. E. Schultes et H. García-Barriga spec. nov.}

Frutex debilis, usque ad 10 ped. altus, leviter ramosus. Folia ramique juvenales rubelli. Ramuli abundantis cum lenticellis ornati. Folia viridia, firme papyracea, elliptica, base rotundata, apice plerumque obtuse et breviter acuminata, non marginata, margine vivo undulata, siccitate $4.5-6.5 \mathrm{~cm}$. longa, $2.5-3.5 \mathrm{~cm}$. lata, supra nitidula, nervo centrale bene impresso, infra pallida, nervo centrale valde elevato; petiolus $4-5 \mathrm{~mm}$. longus. Inflorescentiae axillares, 4-6 cm. longae, praeter partem basilarem multiflorae. Flores: pedicellus comparate robustior, $3-4 \mathrm{~mm}$. longus; calyx viridulus, crassus, tubo $2 \mathrm{~mm}$. longo, glabro, lobis $1 \mathrm{~mm}$. longis, triangularibus, acutis; petala alba sed basi rosea, membranacea, vivo paullo cucullata, rotundata, margine plus minusve irregulares, plerumque $3 \mathrm{~mm}$. longa, $2.5-3 \mathrm{~mm}$. lata; stamina flava, usque ad $1.8 \mathrm{~mm}$. longa, filamentis basi paullo dilatatis, antheris conspicuis, variabiliter $0.8 \mathrm{~mm}$. longis; ovarium elongatum, gratatim ad stylum contractum, basi $0.8 \mathrm{~mm}$. in diametro; stylo brunneolo (ovario cum stylo usque ad $4 \mathrm{~mm}$. longo); stigma conspicuum carnosum, capitatum, $0.5 \mathrm{~mm}$. latum. Fructus carnosus, globosus, apice breviter rostellatus, $8-10 \mathrm{~mm}$. in diametro. 
Columbia: Departamento de Cundinamarca, Chocontá, El Sisga. Alt. 8600 feet. Cultivated in the gardens of the Instituto de Ciencias Naturales, Ciudad Universitaria, Bogotá. December 17, 1983. H. Garcia-Barriga 21366. Type in Herb. Nac. Col. No. 254420; duplicate type in Herb. Gray. Same locality. December 2, 1982. Garcia-Barríga 21345 (Herb. Nac. Col. 236660).

Prunus Betancurii appears to be related to P. Moritziana Koehne and P. ocellata Koehne, both from highland Colombia. From the former, it can be distinguished by its longer and less dense inflorescences with much slenderer axes and shorter and weaker pedicels; furthermore, its leaves are not conspicuously marginate. It differs from the latter species by having longer inflorescences $(2-3 \mathrm{~cm}$. in $P$. ocellata, $4-6 \mathrm{~cm}$. in $P$. Betancurii) which are much more densely flowered; furthermore, its leaves are obtuse or occasionally very short-acuminate as opposed to the long and conspicuously acuminate leaves of $P$. ocellata. The leaves of $P$. Betancurii in life are strongly undulate, whereas in the other two species the leaves appear to be more or less flat. 


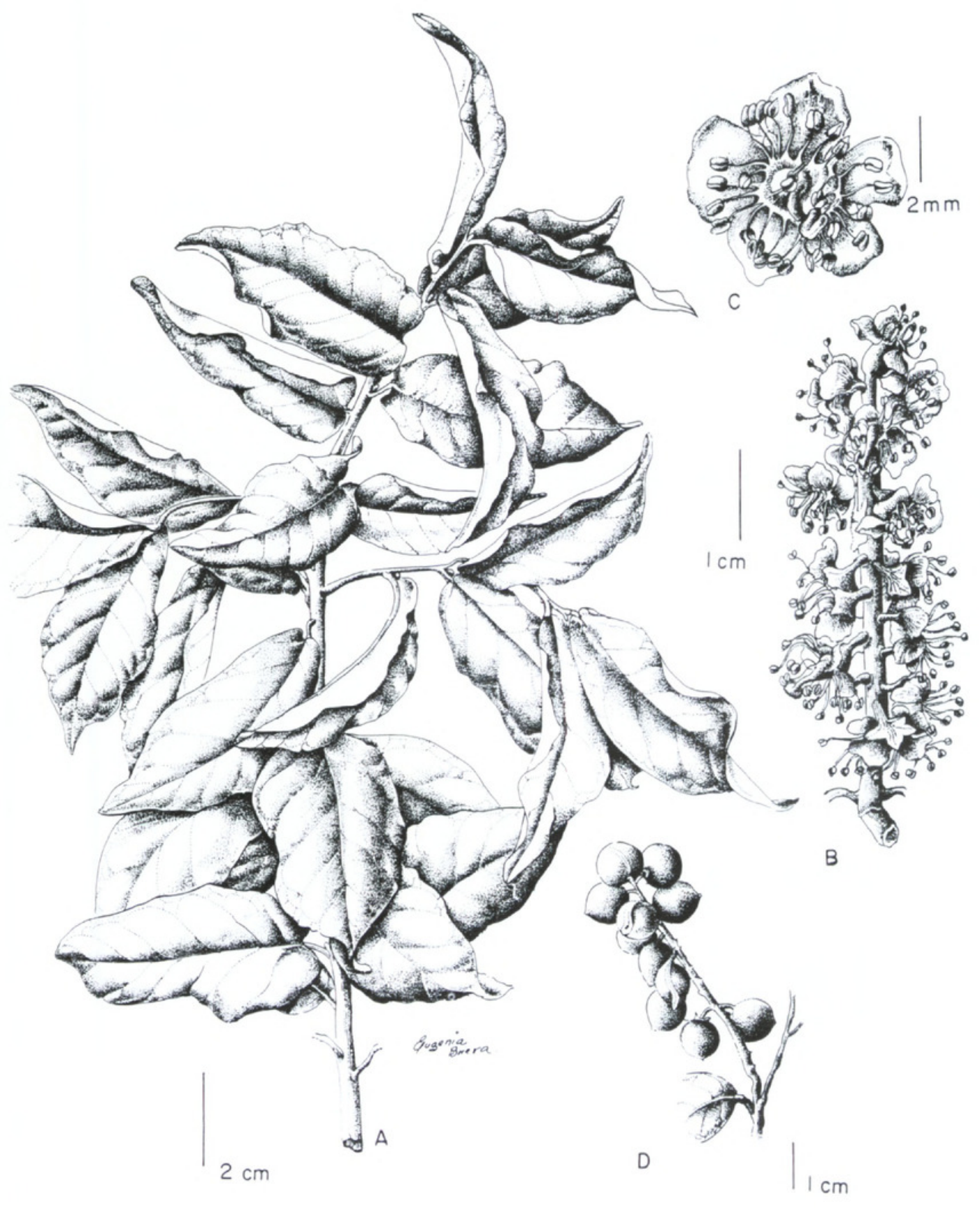

Plate 15. Prunus Betancurii R. E. Schultes et. H. García-Barriga 


\section{$2 \mathrm{BHL}$ Biodiversity Heritage Library}

Schultes, Richard Evans and García-Barriga, Hernando. 1985. "A New Species of Prunus from Colombia." Botanical Museum leaflets, Harvard University 30(2), 91-93. https://doi.org/10.5962/p.168673.

View This Item Online: https://www.biodiversitylibrary.org/item/31877

DOI: https://doi.org/10.5962/p.168673

Permalink: https://www.biodiversitylibrary.org/partpdf/168673

\section{Holding Institution}

Missouri Botanical Garden, Peter H. Raven Library

\section{Sponsored by}

Missouri Botanical Garden

\section{Copyright \& Reuse}

Copyright Status: Public domain. The BHL considers that this work is no longer under copyright protection.

This document was created from content at the Biodiversity Heritage Library, the world's largest open access digital library for biodiversity literature and archives. Visit BHL at https://www.biodiversitylibrary.org. 